\title{
TRANSITIONAL PARADIGM AS AN EXPLANATION FOR THE DEMOCRATIZATION PROCESSES
}

\author{
Gerti Sqapi $^{1}$
}

\begin{abstract}
Over the last quarter of the century, the transitional paradigm (or the approach of the transition) has been a dominant paradigm that has greatly influenced different studies on democratization. The purpose of this paper, in a general perspective, is to conduct an analysis of the transitional paradigm, assumptions, key concepts, and hypotheses developed thereof, in order to evaluate the validity or at least be able to understand and explain the processes of democratization wave that affected third world countries. Development of literature and studies within the conceptual framework of this paradigm was mainly conducted during the period of what is known as "the third wave of democratization." Explanation and direction of change from autocratic to democratic regimes, evident in those countries affected by the third wave, were the main claim of the transition approach. This paper attempts to investigate the validity of the conceptual framework of this approach with respect to the interpretation (and change of directions) of the democratization processes in these countries.
\end{abstract}

UDC Classification: 328, DOI: http://dx.doi.org/10.12955/cbup.v2.467

Keywords: democratization, transitional paradigm, conceptual stretch, consolidation, regime, structural conditions

\section{Introduction}

A little more than two decades ago, it was perhaps typical to see different tyranny or dictatorship come and go, while one tumbled down after the other; the story was finally put on the right side and that liberal democracy had no rival. Given the previous experience of several democratic countries in South Europe and a few countries in South America, driven by the enthusiasm certainly characterized by new developments taking place in the global political landscape in the late 1980s, a growing number of studies and major works started to be published "under the roof" of what was becoming a new (sub) discipline, even promising, academic "transitology." This concept was mostly oriented toward the goal or desire to see democracy prevail in those countries that had just emerged from authoritarian or totalitarian regimes, as well as challenging previous prevailing theories of democratization. It was mainly structuralism or modernization approaches that saw the birth and development of democracy as a slow and evolutionary process and which required the fulfillment of certain preconditions before the goal of the new transitology studies began appearing, so they practically returned to a successful guide for new places that are seeking to democratize. As noted by Schmitter \& Karl (1994), "the claim of these embryonic subdisiplines (transitology and consolidology) is that by applying a universalistic set of assumptions, concepts and hypotheses, they together can explain and hopefully help to guide the way from an autocratic to a democratic regime.”

The new paradigm, and the frame or conceptual apparatus that it offers to understand democratization, went far beyond the "tentative conclusions" of the transitology offered by its founding fathers, stretching and making it a universal paradigm, and claiming the validity and applicability of its assumptions in terrains with unfavorable conditions or contexts that were never originally imagined.

The purpose of this paper is an attempt to conduct a detailed analysis of the transitional paradigm, assumptions, key concepts, and hypotheses developed within it, in order to assess whether, as a universal paradigm, it helps us to better understand democratization or not.

\section{The main assumptions of the transitional paradigm}

We can summarize here six key assumptions that define the transitional paradigm. The first assumption, as Carothers (2002) described as an umbrella for all the others, is that any country moving away from dictatorial rule can be considered a country in transition toward a democracy. Based on this

\footnotetext{
${ }^{1}$ Gerti Sqapi, European University of Tirana, Albania, gerti.sqapi@uet.edu.al
} 
conceptual framework of transitology approach, not only analysts and different promoters of democracy, but also academics, began to treat and explain trends of political changes taking place in different countries of the globe as part or jumping steps toward transition to democracy. Thus, bypassing or without facing much problem with the issue of its "conceptual stretching ${ }^{2}$," for those who quickly embraced this transitology approach and began to see any political change through its lens; practically all the countries in the world enjoy the right of being labelled as "countries in transition to democracy."

The second assumption of this paradigm is that democratization tends to follow or unfold through what is known as a "transition model" consisting of three phases. Opening occurs in the first stage (1), a period of democratic ferment and political liberalization in which cracks appear in the ruling dictatorial regime, with the most prominent fault line being that between hardliners and softliners (Carothers, 2002: 7). Then, in the second stage (2), there follows a breakthrough in the old regime, a time when its collapse occurs and the new democratic system emerges; at this point we have the emergence of political pluralism, formation, or revival of civil society, as well announcement and retention of election - the outcome of which is uncertain. Then, retention of elections, known as founding elections, as well as acceptance of their uncertain results, marks the end of the transition from authoritarian rule and the establishment of democratic governance. Conceptually, as O'Donnell (1994) later clarified, "we are dealing with two transitions: one is the transition to democracy, while the other is the transition towards a democratic regime institutionalized, consolidated." Consolidation of democracy precisely constitutes the third stage (3), according to this model, which refers to the process in which democracy and its institutional framework constitute the only framework of the rules of the game (throughout) society, and where its various political stakeholders and society as a whole are taught, fit, and play conformingly.

The third assumption, derived from the transitional paradigm, is the belief on the crucial importance that the elections have for the path of democratization in countries emerging from authoritarian regimes/dictatorships. So, Carothers (2002) argued that while various promoters of democracy believed in putting the sign of equality between elections and democracy, they tended to hold very high expectations of what genuine elections would do for democratization, believing that they would serve to strengthen and consolidate the democratic institutions of the country, and would serve to broaden and deepen political participation and democratic accountability of the state to its citizens. As Rose \& Shin (2001) noted, various studies at the peak of the third wave of democratization reached so far as to treat electoral competition institutionalization as sufficient to consolidate democracy.

The fourth assumption, which can be understood by a good part of the transition literature, is that the modes of transition from authoritarian rule have significant impacts on stability, shaping, and the prospects of consolidation for the new regime-presumably democratic. In particular, this literature on various modes of transition emphasizes the importance of pacts between elites and other forms of consensus among them that are considered favorable and encouraging for the subsequent process of democratization in a country. As stated by O’Donnell \& Schmitter (1986), “a pact can be defined as an explicit, but not always publicly explicated or justified, agreement among a select set of actors which seeks to define (or better, to redefine) rules governing the exercise of power on the basis of mutual

\footnotetext{
${ }^{2}$ As Philippe C. Schmitter and Terry Lynn Karl have determined, “conceptual streching” of transitology and consolidology is linked with the applicability of their propositions and assumptions to peoples and places never imagined initially. In this essay, the authors explicitly refer to Eastern European and Ex-Soviet Union countries, although the new transitional paradigm had gone much further the "tentative conclusions" offered by its founding fathers, intending for it to be an universal paradigm in understanding and explaining the democratization processes in the world. So, the issue of "conceptual strechting," which Schmitter and Karl referred to, had exceeded beyond the borders of these countries (Schmitter \& Karl, 1994; 173-174).
} 
guarantees for the "vital interests" of those entering into it." Pacts, or agreements between various political actors who lead the transition process, are seen as important to avoid unwanted outcomes (violence or revolts by the mobilized masses); to reduce contingency and inherent uncertainty, which characterizes such a dynamic process; to distribute benefits proportionally among political actors in the game; and above all, to guarantee "vital interests" (not excluding from the political scene) to everyone-those who are in power and challengers in the opposition. As O'Donnell \& Schmitter (1986) determined, "the general scenario for negotiating a pact is clear: it is a situation in which conflicting or competing are interdependent, in that they can neither do without each other nor unilaterally impose their preferred solution on each other if they are to satisfy their respective divergent interests." So, we are dealing with a general stagnation situation where the balance of power between those being challenged (ruling elites) and opposing challengers is not significantly skewed on each side, and where the parties give up the ability to threaten one another guaranteeing the autonomy and vital interests from one another. Negotiations, as well as efforts to reach agreements between the parties, are seen as central in shaping democracy by these authors. According to O'Donnell, Schmitter, Karl, and Przeworski, a democratic outcome is most likely when softliners and moderates enter into pacts that navigate the transition from dictatorship to democracy (McFaul, 2002).

The fifth assumption, which stems from the transitional paradigm, is that "the underlying conditions in transitional countries - their economic level, political history, institutional legacies, ethnic make-up, sociocultural traditions, or other "structural" features - will not be major factors in either the onset or the outcome of the transition process" (Carothers, 2002). Here, we have a significant transitological discontinuity from other democratization approaches that have dominated in political science during the 1950s and 1960s and that have linked democracy in a country setting with the existence of certain and appropriate socioeconomic, structural, or cultural preconditions that needed to exist beforehand. The model proposed by transitologists does not focus on functional or structural factors; on the contrary, "it abandoned the search for functional prerequisites for democracy" (Rustow, 1970) by shifting the attention to the key role that elites or political actors have in the democratization process. Thus by emphasizing the autonomy of political factors, in lieu of social structures, the approach of transitology began to consider the achievement of sustainable democracy in a country as a product of strategic interaction between political elites. Although these elites may be faced with inadequate economic, social, institutional, and cultural conditions in their countries, they are still capable of taking political solutions or strategies needed to lead their country toward democracy. Thus, in 1978 Juan Linz, one of the fathers of transitology, declared that "the real dynamics of political processes should be required to choices made by political actors and not to the social structures” (Kajsiu, 2007). So, the author noted the autonomous role of these political variables in a short and medium term, which even on their own, constituted a powerful changing factor even when they were faced with difficult, non-favoring socioeconomic conditions or a difficult historical/cultural heritage left from previous authoritarian/totalitarian periods.

The sixth assumption, a recent development that we will investigate, which is supported by the transitional paradigm "to the extent that democracy promoters did consider the possibility of statebuilding as part of the transition processes, they assumed that democracy-building and state-building would be mutually reinforcing endeavors or even two sides of the same coin” (Carothers, 2002). So, we are dealing with a tendency to underestimate or set aside the importance of the development of a capable and well-functioning state (in all institutions that comprise the modern state) while a country is in the process of building and developing democracy. This is an implication that the two processes may need to occur parallel to one another. The process of democratization is assumed to include some redesign of state institutions, e.g. the creation of new electoral institutions, parliamentary reform, and 
judicial reform, while ignoring the challenges that a society trying to democratize must face as the reality of building a state from scratch or coping with an existent of largely non-functional state.

\section{Criticism toward theoretical generalization of the transitology conceptual framework for democratization}

So far there are six main assumptions, which can be derived from the conceptual framework of the transitional paradigm. The sixth assumption, from the previous section, is the one that transitologists have claimed not only to explain, but also to help different countries by guiding the path of regime change from authoritarian/totalitarian to a democratic system. Thus, transitologists have claimed that the conceptual framework developed in Southern Europe and Latin America was also valid for Eastern Europe and other geographic regions of the world because "relying on a set of concepts, assumptions, and universal assumptions is possible to explain and even address changes from autocratic regimes to democratic ones" (Kajsiu, 2007). However, such a claim does not seem to be relevant nowadays. The model developed by transitologists and considologists is no longer valid in explaining the political reality of many of those countries in different regions of the world. Although they may have been liberated from long authoritarian/totalitarian rules during the third wave of democratization, they are failing (or seems not to succeed for a very long time) to complete the placement or institutionalization of democracy. In other words, the conceptual framework of the transitional paradigm does not practically coincide with the direction of the democratization process these countries are headed.

As critics of the transitology approach have pointed out, such an approach is essentially characterized by a dimension and strong teleological tendency in itself, which is constructing theoretical democratization model that is mostly oriented toward "telos" (an end purpose), and bypass the understanding of the complexity and the specifications of this process involved. Thus by focusing mostly on the goal, which in this case is the shift of societies emerging from authoritarian regimes toward liberal democracy model, transitologists have tried to submit concrete stages through which democratization is seen to pass. They explained it as a process that goes (almost) in a rational manner and without paying much attention to the specifications of the context of each country. Unlike other approaches with respect to democratization, "the teleological dimension is even more striking in the transitology approach, which virtually ignores the historical and social heritage setting forth the specific stages through which political actors must pass to move a country from authoritarianism to a certain model of liberal democracy" (Kajsiu, 2007. Such an approach, therefore, tends to explain the political changes or transformations almost in terms of a rational process, which progressively and continuously moves toward a predetermined and desired teleological result-the consolidation of democracy in a given country.

Such a critique against this approach has asserted itself through one of its main founding fathers, Guillermo O'Donnell, who "in chastising himself and others, admits that there was a strong teological tendency throughout this literature (Diamond, Plattner, Chu, \& Tien, 1997). "The transitology approach, aside from being criticized as voluntary in its interpretation that goes beyond normative logic, is also wrong and unable to help us understand political developments in many third wave countries, which even though liberated from authoritarian regimes during the period in question, have not gone toward democracy. In fact, the experience of these countries has shown that democratization (as well as other social processes in general) can rarely be explained in terms of a process that moves in a linear, rational, or natural way as claimed by transitologists. Their experience also shows that it is a much more complex process, which includes a multiplicity of factors (structural, social, historical, etc.) that influence its outcome. 


\section{Fall of assumptions}

Now, let us reconsider the analytical focus of the main assumptions of the transition to validate the accuracy of conceptualizing democratization in many third-wave countries and how they may find application on the empirical ground in which they try to explain. On the contrary, it is arguable that any shortcomings of any assumption(s) may question or even reject the usefulness of the transitology conceptual framework in explaining the processes of democratization in these countries.

\section{The fall of the first assumption}

The first assumption of this paradigm, in which every country leaving a dictatorial regime is considered to be "in transition" to democracy, in most cases has proven to be inaccurate and incorrect. Prevalence of semi-authoritarian regimes or authoritarian (also known as hybrid regimes) in many third wave countries, as well as the state of "protracted unconsolidation" of many others, has been confused and even rejected the telos of democratization of the transitional paradigm. Thus, the unidirectional alternative, "in transition to democracy," is also implied to be incorrect and inconsistent with the political reality that it tries to explain. Different political developments or directions, that a good percentage of these third wave countries has taken toward the end of the $20^{\text {th }}$ century and early $21^{\text {st }}$ century, have shown that regime change is quite different from that of a teleological process. Such a reality in the third-wave countries political regimes shows that regime change is not only more complex in itself, but is also producing different variations of regimes (which have been stable for a relatively long time already), and has also rejected the idea of a "natural progress" of their orientation toward democracy. As Levitsky \& Way (2002) stated: "although some hybrid regimes (Mexico, Senegal, Taiwan) underwent democratic transitions in the 1990s, others (Azerbaijan, Belarus) moved in a distinctly authoritarian direction. Still others either remained stable or moved in a multiple direction (Malaysia, Russia, Ukraine, Zambia, Zimbabwe), making the unidirectional implications of the word 'transitional' misleading."

Carothers (2002) also argued that for some years it has been clear that a large number of new regimes are neither democratic in themselves, nor in "transition" toward democracy, and that "the most common political patterns to date among 'transitional countries' - feckless pluralism and dominantpower politics - include elements of democracy but should be understood as alternative directions, not way stations to liberal democracy.”

Although they allow the expression of pluralism and space for opposition parties and civil society, but violate principles and procedures of democracy in their environments continuously, the political developments in these regimes doubt the implication of this first assumption and even that of the transitional paradigm - that they are on their way to democratization. It has become increasingly evident that many of these regimes are not "in transition" from one type of regime to another, but rather use selective mechanisms of democracy to create institutionalized "gray zones" (Karl, 2005). This constitutes the most widespread condition in which most part of the third-wave country regimes are-political models that include multiple (usually informal) restrictions on the functioning of democratic rules and breaking them, which have become their regular or even embedded feature.

\section{The fall of the second assumption}

Also linking with the wrong idea of the telos of democratization is the second assumption of the transitional paradigm, according to which the process of democratization in a country tends to unfold through a model transition consisting of three phases: opening, breakthrough in the old regime, and consolidation - the third and concluding phase of democracy that leads to the establishment and institutionalization of a democratic regime. Thus, according to this "transitional" model, the politicalinstitutional development of democracy in any country is explained in sequential, rational, and linear 
terms of a paradigmatic process, which must be followed by every country freed from a dictatorship or previous authoritarian regime. The ideal of following these rational sequences in the progress of the democratization process of countries and the expectations for a relatively rapid consolidation of democracies in those countries, which constitute difficult cases of democratization (such as due to the unique heritage of their past, their lack of previous historical experiences and institutional ones of democracy, or inadequate structural conditions, etc.), have proven not only to be unrealistic, but also to be inaccurate. Many countries that constitute the majority of attempted democratization, during the so-called "third wave," did not follow this "transitional" model of transitology approach. In contrary, they have devaluated it and have turned down the idea of describing democratization as a process of heading through the finish line (consolidation, or its institutionalization) in rational and linear sequences. As Carothers (2002) noted: "Some of the most encouraging cases of democratization in recent years - such as Taiwan, South Korea, and Mexico - did not go through the paradigmatic process of democratic breakthrough followed rapidly by national elections and a new democratic institutional framework. Their political evolutions were defined by an almost opposite phenomenon extremely gradual, incremental processes of liberalisation with an organized political opposition (not softliners in the regime) pushing for change across successive elections and finally winning.”

Likewise, some countries in South Eastern Europe represent counter examples of regime change, which also reject the idea of following the model of "transition" to democracy after liberation from the old regime. A unique example worth mentioning is Albania (or even Croatia), during the early 1990s, in which the paradigmatic application process was inapplicable to the political trajectory that they followed. Although it could be argued that Albania's transition from the former communist regime toward establishing a governance was a result of the founding elections (or from uncertain results thereof), the first two stages as described earlier in the transition model were relatively successful and rapid; the new transitional regime came on March 22 ${ }^{\text {nd }}, 1992$ from the victory of the anti-communist opposition party (Democratic Party). However, this change of regime did not lead to democracy, instead it led to a new authoritarian rule that lasted at least until 1997. The installation of a new authoritarian system came after Croatia had declared its independence, under the leadership of Franjo Tudjman. Similarly, there are other countries, along with those in the third wave, which did not follow the ideal linear sequences of the "transitional" model in which the democratization process is assumed to undergo.

Furthermore, the consolidation process represents the most problematic phase according to the "transitional" model of democratization. Most of the countries in the third wave, after successfully being freed from their previous authoritarian/totalitarian regimes, managed to install new governments though democratic votes, but failed to successfully create and consolidate sustainable democratic system. Although the conceptual apparatus of transitology approach may be easily applied following the collapse of authoritarian/totalitarian regimes, but it still fails to address or explain the democratic consolidation process. Many of the regimes in these countries continue to suffer today, even after two decades of serious deficits in the functioning of many constituents of democracy. They include deficiencies in the rule of law, the relative weakness/subjugation of other branches of power against the executive, lack of accountability from institutions or the public, questionable electoral conducts and results legitimacy, etc. Guillermo O'Donnell (O’Donnell, 1996), among others, criticized this notion of "consolidation" transitional paradigm as "cases that have not 'arrived' at full institutionalization, or that do not seem to be moving in this direction, are seen as stunted, frozen, protractedly unconsolidated and the like... That some of these polyarchies have been in a state of 'protracted unconsolidation' for some 20 years suggests that there is something extremely odd in about this kind of thinking." 
Therefore, the validity of this notion of "consolidation" against such a situation is irrelevant. As it makes no sense to explain the political developments of countries which have not managed to attain institutionalization of democracy in their environments for over 20 years according to this notion or the "transitional" model.

\section{The fall of the third assumption}

The third assumption of the transitional paradigm, the belief that regular elections will also lead to a deepening of political participation, democratic accountability, or even strengthening/consolidation of democratic institutions for a country in "transition," can also be deemed as failed with evidence deviating from what was expected. There is no denying of the inherent importance that elections have toward democracy, but their holding in such environments of these "transitional" third-wave countries has not led to the expected results based on the transitology approach. The institutionalization of the electoral process in these countries has not done anything except giving fragile legitimacy to regimes that are constantly breaking democratic norms and practices, and do not even respect the civil and political liberties of their citizens. Such a claim was made by Larry Diamond (Encarnacion, 2000) when he noted that in many new "democracies," competitive elections have not provided freedom, accountability, and the rule of law, thus leaving the fate of democracy to remain in balance. He wrote that "to varying but alarming degrees human rights are flagrantly abused; ethnic and other minorities suffer not only discrimination but murderous violence; power is heavily if not regally concentrated in the executive branch; and parties, legislators, executives and judicial systems are thoroughly corrupt.” Likewise, the same argument is given by Andreas Schedler (Schedler, 2002) that fair and competitive elections in the third-wave countries did guarantee no institutionalization of democracy and its constituent components in their environments, when he stated: "while they manage to 'get elections right,' they fail to institutionalize other vital dimensions of democratic constitutionalism, such as the rule of law, political accountability, bureaucratic integrity, and public deliberation." So, in these directions, we can say that the elections are not a successful tool of democratization in many thirdwave countries, and have only partially pushed (despite high expectations of the transitology approach) toward the deep democratic changes in these countries.

\section{The fall of the fourth assumption}

The fourth assumption that stems from the transition literature appears to be quite problematic as well. It is the assumption that different modes of transition have important influences in shaping and consolidating the prospects of new regimes. In particular, transitologists have put the emphasis on pacts and negotiated transitions between elites, as those who create appropriate environments are more favorable to lead the transition to democracy and its consolidation. So, this approach emphasizes the process of strategic interaction between elites as a causal variable that produces successful transitions to democracy. It is not occasional that such a theoretical view of the transitology approach has been severely criticized for a vulnerable understanding of the reality, which does not explain the processes of regime transitions in post-communist world, and even less of an impact that these different ways of transition have had in shaping their subsequent regimes.

Moreover, in the case of those that later proved to be successful regime transitions (as in the case of Czechoslovakia, Poland, Hungary, and Lithuania in 1990), the bargain was not a central feature for them, but was rather a confrontation between those being challenged and the challengers. "The transition is not a bargain, but a confrontation with winners and losers. Though the social-contract metaphor is often employed todescribe constitutional emergence and stability, institutional arrangements that maximize everyone's utility are rare in political world” (McFaul, 2002). Certainly, even in cases of regime transitions in the aforementioned countries, initial negotiations and round table 
discussions between communist regime elites and their opposition challengers took place. In the case of the Polish transition, there was also a power-sharing agreement between the parties for some time. "In some of these transitions, negotations played an important role in starting liberalization processes and impeding potential authoritarian rollbacks. However, the dominant dynamic was still the confrontation, not compromise, between the old elite and new societal challengers" (McFaul, 2002). In contrast to the "successful" transitional model (the strategic situation, the balance of power between the parties, which produce pacted transitions that lead later to democracy) presupposed by transitologists, in the aforementioned cases of Central and Eastern European countries, there were confrontation and imbalance of power in favor of the old regime challengers that facilitated a democratic outcome in their environments. So, the outcomes were quite different from the ideal-type transitions proposed by transitologists. "Democrats with power (a strong popular support), not the process of transition, produced new democratic regimes (in the Czech Republic, Hungary, Poland, Lithuania, etc.). The process of regime transformation was revolutionary, not evolutionary” (McFaul, 2002: 228).

Another point emphasized by the transitional paradigm was the effects of different modes of transition in shaping new regime perspectives. It is argued here (in contrast to transitologists) that different modes of regime transition taking place do not explain the shaping or prospects of consolidating their subsequent regimes. At least if we continue to refer to the experience of post-communist countries, different modes of regime transitions (especially by emphasizing the pacted regime transitions, which transitologists see as the most "successful") have not had any decisive influence on the subsequent democratization processes in their environments. The models and perspectives of democratic consolidation of new regimes, which emerged in the post-communist world, depend entirely on particular and different contexts and conditions compared to those of Latin American and Southern European countries (from which the conceptual model of pacted transitions, as more favorable to produce democracy in a country, was derived). In other words, they were not at all determined simply by the modes of regime transition. Thus, even if we consider the most prominent example of a pacted transition regime in the post-communist world, Moldova, where the distribution of power was relatively equal between the old communist elite and the new challenger elite of the country, we will see that this mode of regime transition did nothing but "created" a partial democracy and a short-lived consolidation (McFaul, 2002), similar to that of its surrounding countries. Also, somewhat similar cases of pacted regime transitions, with gradual balancing of relatively equal power between the old elite and its challenger opposition, include Mongolia, Ukraine, Macedonia, and Albania. However, even in these countries, the modes of regime transition did not lead the shaping of their transitions "successfully" toward democracy at all, unlike the claims by the transitology approach. In fact, their transitions proved to be among the most protracted, or in the worst case ended up as new forms of authoritarianism.

The application of hypotheses on different modes of transition, and their connection with subsequent processes/prospects of democratization in a country, neither applies as a model nor explains the processes of regime transitions in post-communist world. "In addition, the causal pathways (variables) of third-wave countries do not produce the ;right' outcomes in the fourth-wave transitions from communist rule" (McFaul, 2002). "After twenty years, it is difficult to sustain that the mode of transition was an important variable to explain the limits and pitfalls of democracy” (Karl, 2002).

Regardless of the successful cases of democratization in Europe in the 1990s (Czech Republic, Poland, Hungary, Lithuania, etc.), the mode of regime transition was not the reason behind the fate of democracy formed later in their environments. After the collapse of the old regime, there emerged democratic leaders such as Havel, Walesa or Landsbergis, who abided by democratic principles and became a positive factor for their relatively quick and successful democratization. 


\section{The fall of the fifth assumption}

The fifth assumption of the transitional paradigm, which denies the importance of structural conditions in the determination of a successful product in a democratic country despite the initial expectations of transitologists, has not resulted in a successful application in different environments. Despite this emphasis from the transitologists and their almost exclusive focus on processes and institutional changes, structural conditions significantly affect political shaping and its chances to move toward democracy. Thus, socioeconomic, political, sociocultural traditions, and political history, along with specific legacies of the past, all constitute important and considerable factors in making democracy in a given country. Democracy cannot succeed in any sociocultural or socioeconomic environment in the world. Likewise, it cannot succeed in some places where certain structural conditions hindering its development do not change. Let us consider again the paradigmatic example of the most successful case of transitology — the relatively rapid democratization of Spain after Franco's death during the late 1970s and the first five years of the 1980s. "It should be understood that we are talking about a country where the process of economic reform had started in the 1950s, and since then it has seen a rhythm of growth that was second in the world only to Japan for almost two consecutive decades; about a country with a middle and an entrepreneur class who had as much time and was constantly expanding; about a country whose autocratic regime did not substantially violate its institutional heritage, and which had even allowed free thinking and action and the development of civil society" (Wierda, 2001). After Franco's death, “the institutions of democracy were subsequently easy to construct (hence the institutional focus of transitology literature) because so many other basic systems (economic, social, cultural, political) had already been transformed” (Wierda, 2001).

Similarly, the aforementioned cases of democratization in several Central European countries in the 1990s, although very different from the Spanish case, should be understood again in terms of their success in the context of a number of factors and other structural conditions. These countries have emerged from authoritarian/communist regimes, which were less oppressive compared to the totalitarian regimes of other Eastern European countries. They had experienced a degree of liberalization under the communist regime, e.g. the economies of Hungary and Poland were never completely socialized, and were somehow oriented toward free market. Also, they were countries that had experienced a short institutionalized experience with democracy before the establishment of communist regimes and had preserved it in their collective society. Thus, they had a relatively developed civil society after the collapse of their communist regime. They also remembered the immense impact and influence of the EU countries next to them, along with a large and multi-faceted assistance provided in their favor. Therefore, all these constituted important and considerable factors that cannot be ignored, while explaining the democratization of these Central European countries, which have proven to be drastically more complex and transient than the transitology conceptual framework.

\section{The fall of the sixth assumption}

Finally, the sixth assumption of the transitional paradigm is another assumption that has resulted in this problematic approach. We are not referring to the state-building process as a challenge that is secondary to the main process of democratization, as claimed by transitologists, but as a major challenge in itself, which should even precede the establishment of democracy in a country. As Rose \& Shin (2001) argued in their essay, the biggest problem of democracies in the third wave is precisely their democratization turned backwards: "third wave countries have started democratization backwards, introducing free elections before establishing such basic institutions of a modern state such as the rule of law, institutions of civil society and the accountability of governors.” The process of state-building here, beyond the creation of a common national identity, is referred to as "one that goes 
beyond asserting a monopoly on force and creating a basic state framework in order to develop an effective state bureaucracy that can carry out the many functions demanded of a modern state" (Carothers, 2007). Developing such a framework of fundamental state institutions, on which democracy is then built, is not an easy process, which can be carried out within a short time. It is sufficient to remember that countries like Great Britain, France or the United States had become modern states first, then took a long time to establish and consolidate in their environments an effective bureaucracy, rule of law, civil society institutions, etc. All of which was not done so simply through the process of universal suffrage (that even then only existed in a limited form, long after such processes had begun). This is, only to emphasize that state-building processes in many third wave countries should be given special attention as a fundamental challenge that precedes democracy, rather than following it. After all, as Linz \& Stepan (1996) quite explicitly stated that democracy, as a necessary condition, requires a functional state, without which it is impossible. Democracy, in contrast with the claims by transitologists or its various promoters around the world, cannot be built and function properly in the contexts of countries with weak structures and institutions. It is evident that without focusing first on strengthening the capacity of the state itself, the performance of democracy in a given country will always be messy, with setbacks and unstable. What could serve as a good example is the experiences of certain post-communist Balkan and former Soviet Union countries, which substantially and continuously suffered from major deficiencies in the rule of law, poorperforming institutions, very weak civil society, ineffective bureaucracy, etc. Therefore, the enthusiasm of the transitology approach has fallen short in explaining these cases.

\section{Conclusion}

Political upheavals involving different countries of the world, over the past two decades of the twentieth century, have shown that the transformation of their regime toward establishing a wellfunctioning and liberal democracy is not a teleological process. Starting from a teleological view that has mostly characterized the development and flourishing of its literature since its inception, the transitology approach and its conceptual framework offered to guide and explain the democratization processes in these countries. However, it is clear on the empirical level that the political reality of many of the third-wave countries, liberated from their previous authoritarian/totalitarian experiences, did not respond to the expectations and assumptions of the transitional paradigm at all. This transitiology approach has failed to explain the emergence of new regimes in their environments that took different directions. It has become increasingly clear for a long time that the conceptual framework of the transitional paradigm is inadequate to understand the realistic conditions or complex political developments in many of the third-wave countries. Its assumptions are no longer valid in the conceptualization of democratization and are inapplicable on the empirical ground they attempt to explain.

The transitional paradigm, beyond its hopeful vision, has failed to explain various political developments that have taken place (and still do) in many third-wave countries, and more so in its claim to change the direction of these processes toward the institutionalization or "consolidation" of a democratic regime. Continued emphasis or application of these assumptions, concepts and hypotheses of the transitional paradigm in countries, which have gone through a quarter of a century without "consolidation" of their democracy, looks more like an attempt to rectify the facts so as to fit the theory. In fact, "the scientific method in comparative politics means that we do not rectify our conceptual frameworks: instead, we adjust, change, or even discard our theories as new facts come in" (Wierda, 2001). The opposite simply cannot happen. Transitional paradigm has already shown for a long time that it does not fit the reality (phenomenon) that it attempts to explain. New debates, ideas, 
and other conceptual frameworks in the study of democratization are need, certainly without ignoring the context and specifics of each country, where democracy is required to develop.

\section{References}

Bunce, V. (1991). Should Transitologists be Grounded? Slavic Review, 54(1), 111-127.

Carothers, T. (2007). How Democracies Emerge: The “Sequencing” Fallacies. Journal of Democracy, 18(1), 12-27.

Carothers, T. (2002). The End of the Transitional paradigm. Journal of Democracy, 13(1), 5-21.

Diamond, L., Plattner, M. F., Chu, Y., \& Tien H. (Eds.). (1997). Consolidating the Third Wave Democracies: Themes and Perspectives. Baltimore: Johns Hopkins University Press.

Encarnacion, O. G. (2002). Beyond Transitions: The Politics of Democratic Consolidation (Review). Comperative Politics, 32(4), 479-498.

Kajsiu, B. (2007). Demokratizim pa Politikë: Baza Konceptuale e Qasjes Ndërkombëtare në Shqipëri [Democratization without Politics: Conceptual Basis of Access International in Albania]. Tiranë: Revista Polis, 4, 23-38.

Karl, T. L. (2005). From Democracy to Democratization and Back: Before Transitions from Authoritarian Rule. Center on Democracy, Development, and The Rule of Law (CDDRL) Working Papers, 45.

Levitsky, S., \& Way, L. A. (2002). The Rise of Competitive Authoritarianism. Journal of Democracy, 13(2), 51-65.

Linz, J. J., \& Stepan, A. (1996). Problem of Democratic Transition and Consolidation. Baltimore: John Hopkins University Press.

Hobson, C. (2003). Rethinking Democracy: The End of Democratic Transition? Melboune Journal of Politics, 29, 56-67.

Huntigton, S. (1991). Vala e Tretë - Demokratizimi në fund të shekullit të njëzetë [Third Wave - Democratization in the late twentieth century]. Tiranë: Instituti i Studimeve Ndërkombëtare.

Mcfaul, M. (2002). The Fourth Wave of Democracy and Dictatorship - Non-cooperative Transitions in the Post-communist World. World Politics, 54(2), 212-254.

O’Donnell, G., \& Schmitter, P. (1986). Transitions from Authoritarian Rule: Tentative Conclusions about Uncertain Democracies. Baltimore: Johns Hopkins University Press.

O’Donnell, G. (1994). Delegative Democracy. Journal of Democracy, 5(1), 55-69.

O’Donnell, G. (2002). In Partial Defense of an Evanescent Paradigm. Journal of Democracy, 13(3), 6-12.

Rose, R., \& Shin, D. C. (2001). Democratization Backwards: The Problem of Third Wave Democracies. British Journal of Political Science, 31(2), 331-354.

Rustow, D. (1970). Transitions to Democracy: Toward a Dynamic Model. Comparative Politics, 2(3), 337-363.

Schedler, A. (2002). The Menu of Manipulation. Journal of Democracy, 13(2), 36-50.

Schmitter, P. C., \& Karl, T. L. (Spring, 1994). The Conceptual Travels of Transitologists and Consolidologists: How Far to the East Should They Attempt to Go? Slavic Review, 53(1), 173-185.

Wierda, H. J. (2001). Southern Europe, Eastern Europe and Comparative Politics: “Transitology” and the Need for New Theory. East European Politics and Societies,15(4), 485-501. 